\title{
PRODUKSI BENIH PADI GOGO YANG BERMUTU MENGGUNAKAN TEKNIK DAN WAKTU PENYIMPANAN
}

\author{
PRODUCTION OF QUALITY UPLAND RICE SEEDS USING \\ STORAGE TECHNIQUES AND TIME \\ Eko Priyantono $^{1}$, Maemunah ${ }^{1}$, Moh. Adnan Khaliq ${ }^{1}$, Mustakim ${ }^{1 *}$, Yusran ${ }^{2}$ \\ ${ }^{1}$ Program Studi Agroteknologi, Fakultas Pertanian Universitas Tadulako \\ ${ }^{2}$ PLP Fakultas Pertanian Universitas Tadulako \\ Jl. Soekarno Hatta No.KM. 9, Tondo, Mantikulore, Kota Palu, Sulawesi Tengah
}

\begin{abstract}
ABSTRAK
Penyimpanan sangatlah penting dilakukan untuk menghasilkan benih padi gogo yang bermutu dan berkualitas yang akan digunakan sebagai bahan tanam selanjutnya. Tujuan dari penelitian ini ialah untuk mendapatkan teknik produksi benih padi gogo yang bermutu dan berkualitas dengan perkecambahan terbaik. Penelitian ini dilaksanakan di desa Kalukubula dan uji perkecambahan dilaksanakan di Laboratorium Ilmu dan Teknologi Benih. Penelitian ini dilaksanakan pada bulan Oktober 2019 sampai Februari 2020. Penelitian ini disusun menggunakan racangan acak kelompok (RAK) pola faktorial dua faktor, faktor pertama terdiri atas dua lokasi penyimpanan yaitu: $\mathrm{P} 1=$ Dalam Ruangan, $\mathrm{P} 2=\mathrm{Luar}$ Ruangan, Sedangkan faktor kedua terdiri atas tiga waktu penyimpanan yaitu: $\mathrm{W} 1=$ satu bulan dan $\mathrm{W} 2=$ dua bulan, dan W3= tiga bulan, yang diulang sebanyak enam kali sehingga terdapat 36 unit percobaan dimana setiap unit percobaan terdapat 50 benih dan total benih yang digunakan ialah sebanyak 1.800 benih. Analisis data menggunakan uji Fisher dan dilanjutkan dengan menggunakan uji BNJ pada taraf $1 \%$. Hasil penelitian menunjukkan hasil panen yang disimpan dalam ruangan selama 3 tiga bulan menghasilkan daya berkecambah $(93,00 \%)$, waktu berkecambah $(2,08$ hari), potensi tumbuh maksimum $(99,00 \%)$ dan persentase benih berjamur $(1,33 \%)$.
\end{abstract}

Kata kunci: Benih padi, Bermutu, Teknik, Waktu penyimpanan

\begin{abstract}
Storage is very important to do to produce quality and quality upland rice seeds that will be used as the next planting material. The purpose of this study was to obtain high quality upland rice seed production techniques with the best germination. This research was conducted in Kalukubula village and the germination test was carried out at the Laboratory of Seed Science and Technology. This research was conducted from October 2019 to February 2020. This research was arranged using a two-factor factorial randomized block design (RAK), the first factor consisting of two storage locations, namely: $P 1=$ Indoors, $P 2=$ Outdoor, while the second factor consists of three storage times, namely: $W 1=$ one month and $W 2=$ two months, and $W 3=$ three months, which is repeated six times so that there are 36 experimental units where each experimental unit contains 50 seeds and the total seeds used are 1,800 seeds. The results showed that the yields stored in the room for 3 three months resulted in germination (93.00\%), germination time (2.08 days), maximum growth potential (99.00\%) and the percentage of moldy seeds (1.33\%).
\end{abstract}

Keywords: Rice seeds, Quality, Technique, Storage time

\section{Pendahuluan}

Teknik penyimpanan untuk menghasilkan bahan tanam selanjutnya sangatlah penting diketahui karena gebah yang baru dipanen masih memiliki kadar air yang cukup tinggi, sehingga diperlukan penanganan khusus untuk

${ }^{*}$ Penulis Korespondensi.

E-mail: takimcfc@gmail.com menurunkan kadar air dan mempertahankan mutu serta kualitas benih. (Mustakim et al., 2020.)

Hasil penelitian (Dewi, 2015) Menunjukkan bahwa kombinasi lokasi dan waktu penyimpanan memberikan pengaruh yang berbeda terhadap pertambahan kadar air dan bobot benih, tetapi tidak berpengaruh nyata 
terhadap daya tumbuh benih dan kerusakan benih. Penyimpanan tiga bulan memberikan pertambahan kadar air dibanding dengan kontrol dan penyimpanan selama satu bulan.

Pengeringan dengan sinar matahari yang tidak menentu dapat menurunkan kadar air hingga kadar air yang terendah dan dapat menyebabkan kerusakan embrio pada benih sehingga benih tidak dapat tumbuh lagi, (Bettaieb Rebey et al., 2019; Wulandari, 2019). Pengeringan disinar matahari juga dapat mengurangi waktu beraktivitas ataupun beristirahat karena benih yang dikeringkan akan selalu diperhatikan dan diawasi dari serangan hewan yang dapat merusak benih yang dikeringkan tersebut.

Salah satu faktor yang dapat menurunkan mutu dan kualitas benih ialah kadungan air yang ada dalam benih (kadar air benih), untuk itulah penurunan kadar air benih sangatlah penting dilakukan. Salah satu upaya untuk mengatasi penurunan mutu dan kualitas benih yaitu dengan cara pengeringan dengan menggunakan metode penyimpanan, selain tidak mengganggu aktifitas dan waktu istirahat juga dapat mencegah dari serangan hewan serta mencegah kerusakan embrio saat pengeringan sinar matahari.

Penelitian mengenai penanganan pasca panen sangatlah penting untuk dilakuakan karena dengan penanganan pasca panen yang baik dapat menghasilkan benih yang bermutu dan berkualitas sehingga dapat digunakan sebagai bahan tanam selanjutnya.

Tujuan dari penelitian ini ialah untuk mendapatkan teknik produksi benih padi gogo yang bermutu dan berkualitas dengan perkecambahan terbaik.

\section{Metode Penelitian}

Penelitian ini dilaksanakan di desa Kalukubula dan uji perkecambahan dilaksanakan di Laboratorium Ilmu dan Teknologi Benih. Penelitian ini dilaksanakan pada bulan Oktober 2019 sampai Februari 2020.

Alat yang digunakan antara lain cawan petri, pinset, plastik, kertas label, alat perkecambahan, kamera dan alat tulis menulis. Bahan yang digunakan antara lain benih kultivar Kalendeng yang baru dipanen dan kertas merang.

Penelitian ini disusun menggunakan racangan acak kelompok (RAK) pola faktorial dua faktor, faktor pertama terdiri atas dua lokasi penyimpanan yaitu: $\mathrm{P} 1=$ Dalam Ruangan, $\mathrm{P} 2=$ Luar Ruangan, Sedangkan faktor kedua terdiri atas tiga waktu penyimpanan yaitu: $\mathrm{W} 1=$ satu bulan dan $\mathrm{W} 2=$ dua bulan, dan $\mathrm{W} 3=$ tiga bulan, yang diulang sebanyak enam kali sehingga terdapat 36 unit percobaan dimana setiap unit percobaan terdapat 50 benih dan total benih yang digunakan ialah sebanyak 1.800 benih.

Penelitian diawali dengan memanen kultivar Kalendeng dan langsung menggantungnya di dua tempat yang berbeda dengan lama waktu penggantungan yang berbeda sebagai perlakuan tanpa harus mengeringkannya terlebih dahulu. Perkecambahan benih dilakukan setiap bulannya selama tiga bulan.

Perkecambahan benih menggunakan uji diatas kertas merang, (Sadjad and Suseno, 1972). Parameter yang diamati ialah sebagai berikut: daya berkecambah, potensi tumbuh, waktu berkecambah, persentase benih berjamur dan persentase kecambah berjamur dihitung pada hari ke 14 dengan menggunakan rumus, (Sadjad et al., 1997).

$$
\begin{aligned}
& \mathrm{DB}=\frac{\text { Benih yang berkecambah normal }}{\text { Benih yang dikecambahkan }} \times 100 \\
& \mathrm{PTM}=\frac{\text { Benih yang berkecambah }}{\text { Benih yang dikecambahkan }} \times 100
\end{aligned}
$$

Waktu berkecambah $=\frac{\mathrm{N} 1 . \mathrm{T} 1+\mathrm{N} 2 . \mathrm{T} 2+\cdots \mathrm{Ni} . \mathrm{Ti}}{\text { Benih yang berkecambah }}$

Keterangan:

$\mathrm{N} 1=$ Benih yang berkecambah

$\mathrm{T} 1=$ Hari berkecambah

$\mathrm{Ni}=$ Benih berkecambah hari berikutnya

$\mathrm{Ti}=$ Hari berkecambah berikutnya

Benih berjamur $=\frac{\text { Jumlah Benih berjamur }}{\text { Total benih dikecambah }} \times 100$

Benih berjamur $=\frac{\text { Jumlah Kecambah berjamur }}{\text { Total benih berkecambah }} \times 100$

\section{Hasil dan Pembahasan}

\section{Daya Kecambah}

Hasil Uji BNJ Taraf 1\% menunjukkan bahwa penyimpanan di dalam ruangan menghasilkan nilai rata-rata daya kecambah yang lebih tinggi setelah disimpan selama dua bulan dan tiga bulan dan berbeda nyata dengan penyimpanan selama satu bulan.

Penyimpanan di luar ruangan menghasilkan daya kecambah tertinggi setelah disimpan selama dua bulan dan berbeda nyata dengan penyimpanan selama satu bulan namun tidak berbeda nyata dengan penyimpanan selama tiga bulan. 
Tabel 3. Nilai rata-rata potensi tumbuh maksimum (\%)

\begin{tabular}{|c|c|c|c|c|}
\hline \multirow{2}{*}{ Tempat Penyimpanan } & \multicolumn{3}{|c|}{ Lama Waktu Penyimpanan } & \multirow{2}{*}{ BNJ 1\% } \\
\hline & Satu Bulan & Dua Bulan & Tiga Bulan & \\
\hline $\begin{array}{l}\text { Penggantungan Dalam } \\
\text { Ruangan }\end{array}$ & $\mathrm{p} 92,67^{\mathrm{a}}$ & $\mathrm{p} 96,67^{\mathrm{b}}$ & ${ }_{\mathrm{q}}^{99} 9,00^{\mathrm{c}}$ & \multirow[b]{2}{*}{1,49} \\
\hline $\begin{array}{c}\text { Penggantungan Luar } \\
\text { Ruangan }\end{array}$ & $\mathrm{q} 98,67^{\mathrm{b}}$ & $\mathrm{p} 96,00^{\mathrm{a}}$ & $\mathrm{p} 96,00^{\mathrm{a}}$ & \\
\hline BNJ 1\% & \multicolumn{4}{|c|}{1,71} \\
\hline \multicolumn{5}{|c|}{$\begin{array}{l}\text { Keterangan: Angka yang diikuti oleh huruf yang sama pada baris }(a, b, c) \text { dan kolom }(p, q) \text { yang sama tidak } \\
\text { menunjukkan perbedaan }\end{array}$} \\
\hline \multicolumn{2}{|c|}{$\begin{array}{l}\text { Persentase Benih Berjamur } \\
\text { Hasil uji BNJ pada taraf 1\% menunjukkan } \\
\text { bahwa perlakuan penyimpanan dalam ruangan } \\
\text { menghasilkan persen benih berjamur yang lebih }\end{array}$} & \multicolumn{3}{|c|}{$\begin{array}{l}\text { sedikit pada penyimpanan selama tiga bulan dan } \\
\text { berbeda nyata dengan penyimpanan selama satu } \\
\text { bulan namun tidak berbeda nyata dengan } \\
\text { penyimpanan selama dua bulan. }\end{array}$} \\
\hline
\end{tabular}

\begin{tabular}{|c|c|c|c|c|}
\hline \multirow{2}{*}{ Tempat Penyimpanan } & \multicolumn{3}{|c|}{ Lama Waktu Penyimpanan } & \multirow{2}{*}{ BNJ 1\% } \\
\hline & Satu Bulan & Dua Bulan & Tiga Bulan & \\
\hline $\begin{array}{c}\text { Penggantungan Dalam } \\
\text { Ruangan }\end{array}$ & $\mathrm{q}^{29,67^{\mathrm{c}}}$ & $\mathrm{p}^{3}, 67^{\mathrm{a}}$ & ${ }_{q} 6,00^{b}$ & \multirow[b]{2}{*}{1,31} \\
\hline $\begin{array}{c}\text { Penggantungan Luar } \\
\text { Ruangan }\end{array}$ & ${ }_{\mathrm{p}} 5,00^{\mathrm{b}}$ & $\mathrm{p} 3,67^{\mathrm{a}}$ & $\mathrm{p}^{4}, 33^{\mathrm{ab}}$ & \\
\hline BNJ 1\% & \multicolumn{4}{|c|}{1,51} \\
\hline
\end{tabular}

Keterangan: Angka yang diikuti oleh huruf yang sama pada baris $(a, b)$ dan kolom $(p, q)$ yang sama tidak

\section{Pembahasan} menunjukkan perbedaan

Hasil penelitian menunjukkan bahwa penyimpanan hasil penen didalam dan luar ruangan yang disimpan selama dua bulan merupakan perlakuan yang terbaik untuk menghasilkan bahan tanam yang bermutu karena dapat menghasilkan daya kecamah yang lebih tinggi, waktu berkecambah yang lebih cepat dan persentase benih dan kecambah berjamur yang lebih rendah.

Hasil penelitian (Mustakim et al., 2020) melaporkan bahwa hasil panen yang disimpan dengan cara digantung diluar ruangan selama tiga bulan menghasilkan daya berkecambah $(71,00 \%)$, waktu berkecambah (2,23 hari), persentase benih berjamur $(9.33 \%)$, dan persentase kecambah berjamur (9.33\%).

Penyimpanan selama dua bulan diduga benih telah mengalami penurunan kadar air hingga kadar air terbaik untuk pertumbuhan kecambah, karena dengan Kadar air yang tinggi dapat menghambat pertumbuhan kecambah dan jika kadar air yang terlalu rendah juga dapat menghambat pertumbuhan kecambah. Ance, (1992) menyatakan bahwa tinggi rendahnya kandungan air dalam benih memegang peranan yang demikian penting dan berpengaruh besar terhadap viabilitas dan pertumbuhan benih tersebut.

Sun dan Leopold, mengemukakkan bahwa meningkatnya kadar air dan kelembaban menyebabkan kerusakkan protein meningkat. Kadar air tingkat rendah, benih yang disimpan pada kadar air 4 sampai 5\% tidak dipengaruhi oleh cendawan, tetapi benih benih tersebut memeliki umur simpan yang lebih pendek dari pada kadar air yang disimpan pada kadar air yang lebih tinggi, (Yulyatin dan Haryati, 2016). Justice dan Bass, (2002) mengemukakan bahwa kadar air merupakan faktor yang paling penting mempengaruhi kemunduran benih, kemunduran benih meningkat sejalan dengan meningkatnya kadar air benih.

Sutopo, (2002) menyatakan bahwa benihbenih dengan viabilitas awal yang tinggi lebih tahan terhadap kelembaban serta temperatur tempat penyimpanan yang kurang baik dibanding dengan benih-benih yang memiliki viabilitas awal yang rendah.

Penurunan dan peningkatan perkecambahan (daya dan waktu berkecambah serta potensi tumbuh maksimum) yang disimpan didalam dan luar ruangan pada bulan kedua dan 
ketiga diakibatkan oleh kadar air benih yang berubah-ubah, dimana benih bersifat higroskopis, yang artinya benih mudah menyerap air yang ada dilingkangan luar benih jika kadar air benih lebih rendah dibanding kelembaban udara.

Hendarto, (2007) menyetakan benih bersifat hogroskopis (mudah menyerap air) dan selalu mencapai kondisi equilibrium dengan lingkungannya. Dewi, (2015) juga menyatakan ketika kelembaban udara tempat penyimpanan benih sangat tinggi dimana kadar airnya lebih tinggi dari pada kadar air benih, maka benih akan menyerap kadar air dari udara sehingga kandungan airnya juga meningkat.

Dinarto, (2010) menyatakan Kelembaban relatif udara sekitar benih meningkat (tinggi), maka kadar air benih akan meningkat pula sampai terjadinya nilai keseimbangan antara kadar air benih danga kelembaban relatif udara sekitar. Hasil penelitian Dewi, (2015) menunjukkan kadar air $10 \%$ dan lama penyimpanan tiga bulan menjadikan pertambahan kadar air tertinggi dibanding perlakuan yang lain. Baco et al., (2000) menyatakan bahwa kadar air benih yang sama pada awal penyimpanan dapat bervariasi selama penyimpanan, tergantung pada kelembaban ruang simpan dan kekedapan ruang simpan bahan pengemas (wadah) yang digunakan dalam penyimpanan.

Penurunan dan peningkatan perkecambahan (daya dan waktu berkecambah serta potensi tumbuh maksimum) juga dipengaruhi oleh faktor genetik, dimana tanaman yang memiliki genetik yang unggul maka pertumbuhannya lebih dominan dipengaruhi oleh genetik tanaman itu sendiri dibanding faktor lingkungan. Hal ini dapat terlihat pada penyimpanan didalam dan diluar ruangan pada bulan ketiga masih tergolong penyimpanan yang terbaik karena masih menghasilkan pertumbuhan kecambah lebih dari 85\%. Mustakim et al., (2019) menyatakan bahwa tanaman yang memiliki genetik yang unggul maka pertumbuhannya akan baik walaupun sedikit mengalami penurunan yang diakibatkan oleh faktor lingkungan yang berubah-ubah.

Penurunan dan peningkatan perkecambahan (daya dan waktu berkecambah serta potensi tumbuh maksimum) juga dipengaruhi oleh kultivar. Kultivar merupakan kumpulan dari beberapa galur (bergalur banyak) dimana setiap galur memiliki sifat yang berbeda- beda, itulah yang menyebabkan perkecambahan yang bervariasi.

Penurunan perkecambahan (daya dan waktu berkecambah) pada penyimpanan di luar ruangan yang disimpan selama tiga bulan diakibatkan terjadinya peningkatan kadar air benih, sebab benih yang digantung dan disimpan diluar ruangan dapat berhubungan langsung dengan udara bebas (aliran udara). Dinarto, (2010) menyatakan bahwa penyimpanan benih secara terbuka, udara sekitar dapat berhungan langsung dengan ruang penyimpanan sehingga akan mempengaruhi kadar air benih dan benih bersifat higroskopis maka kelembaban udara yang relatif tinggi akan menyebabkab kadar air benih meningkat sampai mencapai keseimbangan dan juga akan mempengaruhi viabilitas benih.

Hasil penelitian (Lesilolo et al., 2012) bahwa penyimpanan benih jagung pada ruang terbuka akan lebih cepat mengalami kemunduran atau daya simpan menjadi lebih singkat akibat fluktuasi suhu dan kelembaban. Hal ini karena ruang simpan terbuka berhubungan langsung dengan lingkungan diluar ruangan melalui jendela dan ventilasi.

Peningkatan persentase benih dan kecambah berjamur pada penyimpanan luar ruangan yang disimpan selama tiga bulan diguga karena kadar air benih mengalami peningkatan akibat benih menyerap air pada lingkungan yang mempunyai kelembaban relatif lebih tinggi yang diakibatkan oleh aliran udara bebas yang ada dilingkungan. Peningkatan kadar air benih dan kelembaban udara dapat mempengaruhi dan mendukung perkembangan mikroba dan jamur yang dapat merusak benih dan kecambah.

Benih yang digantung dan disimpan diluar ruangan spora jamur yang dibawa oleh angin sangat mudah menempel pada benih dan ketika benih dikecambahkan maka jamurpun ikut tumbuh dan menginfeksi dan merusak benih dan kecambah. Sitorus dan Imam, (2000) menyatakan bahwa faktor yang mempengaruhi perkembangan mikroba adalah tingginya suhu dan kelembaban selama penyimpanan. Kartono, (2004) menyatakan bahwa serangga dan mikroba mudah berkembang biak bila benih yang disimpan mempunyai kadar air $>12 \%$ kelembaban relatif penyimpanan $>80 \%$.

Dinarto, (2010) menyatakan bahwa pengeringan adalah upaya untuk menurunkan kadar air benih agar benih tahan disimpan lama, tidak mudah diserang hama dan terkontaminasi cendawan, mempertahankan volume dan bobot benih sehingga memudahkan penyimpanan. 
Jurnal Ggratech 11 (2) 79-84, Desember 2021

Chope et al., (2006) menyatakan bahwa semakin baik kualitas benih terutama berkaitan dengan kebersihan sumber pathogen, maka persentase yang tumbuh juga semakin tinggi pula.

\section{Kesimpulan}

Hasil panen yang disimpan dalam ruangan selama 3 tiga bulan menghasilkan daya berkecambah $(93,00 \%)$, waktu berkecambah (2,08 hari), potensi tumbuh maksimum $(99,00 \%)$ dan persentase benih berjamur $(1,33 \%)$.

\section{Ucapan Terima Kasih}

Penulis mengucapkan terimakasih kepada teman yang telah banyak membantu dalam proses penelitian dan penulisan karya ilmiah baik dalam bentuk jasa maupun materi.

\section{Daftar Pustaka}

Ance, dan K. Kartasapoetra 1992. Teknologi Benih. Jakarta: Rineka Cipta.

Baco, D., M. Yasin., J. Tandiabang., S. Saenong., dan T. Lando, 2000. Penanggulangan Kerusakan Benih Jagung Oleh Hama Gudang Sitophilus zeamais Dengan Berbagai Alat dan Cara Penyimpanan. Penelitian Pertanian Tanaman Pangan. 19(1): 1-5.

Bettaieb Rebey, Iness et al. 2019. “On the Effect of Initial Drying Techniques on Essential Oil Composition, Phenolic Compound and Antioxidant Properties of Anise Seeds." Journal of Food Measurement and Characterization.

Chope, G.A., L.A. Terry, dan P.J. White, 2006. Effect of Controlled Atmosphere Storage on Abscisic Acid Concentration and Other Biochemical Attributes of Onion Bulbs. Postharvest Biology and Technology. 39: 233-242.

Dewi, T.K. 2015. Pengaruh Kombinasi Kadar Air Benih dan Lama Penyimpanan Terhadap Viabilitas dan Sifat Fisik Benih Padi Sawah Kumtivar Ciherang. Jurnal Agrorektan. 2(1): 53-61

Dinarto, W. 2010. Pengaruh Kadar Air dan Wadah Simpan Terhadap Viabilitas Benih Kacang Hijau dan Populasi Hama Kumbang Bubuk Kacang Hijau Callosobruchus Chinensis L. Jurnal AgriSains. 1(1): 68-78.

Hendarto, K. 2007. Teknologi Pemrosesan Pengemasan da Penyimpanan Benih. Yogyakarta: Kanisius
e-ISSN : 2621-7236

p-ISSN : 1858-134X

Justice, O.L., dan L.M. Bass, 2002. Prinsip dan Praktek Penyimpanan Benih. PT. Raja Grafindo Persada. Jakarta.

Kartono, 2004. Teknik Penyimpanan Benih Kedelai Varietas Wilis Pada Kadar Air dan Suhu Penyimpanan yang Berbeda. BuletinTeknik Pertanian. 9(2): 79-82.

Lesilolo, M.K., J. Patty., and N. Tetty, 2012. Penggunaan Desikan Abu dan Lama Simpan Terhadap Kualitas Benih Jagung Pada Penyimpanan Ruang Terbuka. Agrologia. 1(1): 51-59.

Sutopo, L. 2002. Teknologi Benih. Jakarta: PT. Raja Grafindo Persada.

Mustakim., S. Samudin., And Maemunah, 2019. Establishment of Genetic Variability, Heritability and Correlation Between the Charateristic of Several Local Upland Rice Cultivar. Agroland: The Agriculture Sciance Journal. 6(1).

Mustakim, A. Syakur, M.A. Khaliq, dan Yusran, 2020. Penanganan Pasca Panen Dengan Metode Penyimpanan Untuk Menghasilkan Benih Padi Gogo Lokal Yang Berkualitas. Agrotech, 10(2): 48-53

Sadjad, S, and P.D.I.H Suseno, 1972. "Kertas Merang Untuk Uji Viabilitas Benih Di Indonesia Beberapa Penemuan Dalam Bidang Teknologi Benih.

Sadjad, S. 1997. "Membangun Industri Benih Dalam Era Agribisnis Indonesia." Gramedia. PT. Jakarta

Sitorus, E. M., dan Imam, 2000. Pengaruh Pendinginan Awal dan Suhu Penyimpanan Untuk Memperpanjang Kesegaran Bawang Merah. J.Hort. 10(2): 137-143.

Sun, W. Q., and A. C. Leopold, 1994. Glassy State and Seed Stroge Stability: A Viability Equation Analysis. Annals of Botany. 74: 601-604.

Wulandari, F. 2019. "Kajian Distribusi Suhu Dan Aliran Udara Panas Pada Alat Pengering Gabah Tipe Hibrid Menggunakan Simulasi Computational Fluid Dynamics (CFD)."

Yulyatin, A., dan Y, Haryati, 2016. Pengujian Daya Berkecambah Biji Bawang Merah Selama 7 Periode Simpan. Buletin Hasil Kajian. 6(6): 5-8 